\title{
Thyroid Cancer Clinical TNM Finding v7
}

National Cancer Institute

\section{Source}

National Cancer Institute. Thyroid Cancer Clinical TNM Finding v7. NCI Thesaurus. Code C89157.

A clinical finding about one or more characteristics of thyroid cancer, following the rules of the TNM AJCC V7 classification system. The assessment of a thyroid tumor depends on inspection and palpation of the thyroid gland and regional lymph nodes. Indirect laryng oscopy to evaluate vocal cord motion is essential. A variety of imaging procedures can provide additional useful information. These include radioisotope thyroid scans, ultrasonog raphy, computed tomog raphy scans (CT), magnetic resonance imaging (MRI) scans, and PET scans. The diagnosis of thyroid cancer must be confirmed by needle biopsy or open biopsy of the tumor. (from AJCC 7th Ed.) 